\title{
Diagnostic potential of lysosomal hydrolases in body cavity effusions
}

\author{
MALCOLM MCCORMACK
}

From the Department of Pathology, University Medical Buildings, Foresterhill, Aberdeen AB9 2ZD

SYNOPSIS Hexosaminidase, $\alpha$-mannosidase, $\beta$-galactosidase, $\beta$-glucuronidase, and arylsulphatase A $\mathrm{A}_{\mathcal{S}}$ were measured in peritoneal and pleural effusions from patients with benign, malignant, and inflam $-\overline{\widehat{O}}$ matory disorders. Compared with the benign transudates, all enzyme activities were moderately elevated in malignant effusions and markedly elevated in inflammatory effusions. The assay of hexosaminidase and $\alpha$-mannosidase indicated clearly the underlying pathology in most specimens $\stackrel{\sim}{\sim}$ studied. This method could be of clinical value when the cause of an effusion is in doubt, particularly $A$ since the diagnostic criteria are independent of the presence or absence of tumour cells in the aspirate.오

The diagnosis of a body cavity effusion as malignant is most convincingly made by the demonstration of malignant cells in the aspirate. However, the accuracy of effusion cytology is very variable, ranging from $56 \%-91 \%$ (Rome, 1964; Graham, 1964), and malignant cells are found more readily in peritoneal than in pleural effusions. Many non-cytological methods for the differentiation between benign and malignant effusions have been proposed, but none has enjoyed more than transient popularity. They have included estimation of the effusion erythrocyte content (Tinney and Olsen, 1945), protein concentration (Carr and Power, 1958), metallic ion content (Dines et al, 1974), and the activities of various lysosomal enzymes (Pineda et al, 1962). One of the most recent and promising of the latter methods involves the simultaneous measurements of the protein and lactate dehydrogenase content of both serum and effusion (Light et al, 1972). This method appears reliably to separate transudates from exudates but cannot distinguish between inflammatory and malignant exudates.

For several years there has been interest in this laboratory in the relationships between malignant cells and lysosomal enzymes, and in particular that subgroup known as the glycosidases. This interest is relevant to the theory that malignant cells elaborate enzymes which catabolize glycosaminoglycans (the compounds which are largely responsible for imparting viscosity to intercellular ground substance) to low-molecular weight, low-viscosity subunits. Accordingly, malignant cells may thus infiltrate in a medium so radically altered as to present a much

Received for publication 8 September 1975 reduced mechanical barrier to invasion. It was: decided to investigate the activities of various lyso-⿳亠丷厂巾 somal enzymes in a variety of body cavity effusions to assess whether any discernible patterns, possibly $\overrightarrow{0}$ of future clinical significance, emerged. The fiseos enzymes detailed below were chosen either because they have been shown to be present in malignamit cells, or because their known properties make? likely that they are involved in the breakdown of glycosaminoglycans to soluble oligosaccharides. के Arylsulphatase $\mathrm{A}$ is not a glycosidase but has been included because recent research suggests that ito shows an increased activity in malignant tumours.

1. $\beta$-Glucuronidase ( $\beta$-D-glucuronide glucurono hydrolase: EC 3.1.1.31)

This acid hydrolase has been extensively investigatedo with respect to its possible role in malignancy. It is known to play an important part in the catabolismo of glycosaminoglycans (Feher et al, 1971; Hall et al, 1973) and has higher activities in malignane tumours than in their normal tissues of origin (Fishman et al, 1947; Carr, 1965; Kroh and? Renkawek, 1973). Serum increases occur in malig సٓ nant disease (Goldbarg et al, 1959), but elevated" levels are not invariable, and increased serum activity also can be found in a variety of liver disorders (Pineda et al, 1959), varicose veins (Niebes, 1972) O and diabetes (Belfiore et al, 1972). Tissue $\beta$-glucuo ronidase is elevated in inflammation (Feher et al: 1971).

2. $\alpha$-Mannosidase ( $\alpha$-D-mannoside mannohydro lase: EC 3.2.1.24)

Relatively little investigation of this enzyme ha范 
taken place, but it is increased in vaginal fluid in carcinoma of the cervix (Lawson, 1960) and catabolizes glycosaminoglycans (Woessner, 1965).

\section{Arylsulphatase (aryl-sulphate sulphohydrolase:} EC 3.1.6.1)

Three arylsulphatases have been distinguished, arylsulphatases A and B being associated with lysosomes, and arylsulphatase $\mathrm{C}$ having a microsomal location. The $\mathbf{A}$ and $\mathbf{B}$ isoenzymes are soluble (in common with other lysosomal hydrolases) whereas the $\mathrm{C}$ isoenzyme is insoluble. Arylsulphatase B has not yet been assigned a natural substrate, but some authors believe that it has a place in ground substance degradation (Farooqui and Bachhawat, 1971). Arylsulphatase A breaks down cerebroside sulphate esters (Hook et al, 1973) and is probably produced by malignant cells (Schersten et al, 1971). Total sulphatase activity is increased in the urine of patients with inflammatory or malignant disease (Boyland et al, 1955; Dzialoszynski, 1957).

Baum et al (1959) developed the differential assay of the two lysosomal arylsulphatases, but personal experience has shown the measurement of arylsulphatase B with commercially procured substrate to be both capricious and expensive. For this reason only arylsulphatase A was assayed in the present investigation.

4. $\beta$-Galactosidase ( $\beta$-D-galactoside galactohydrolase: EC 3.2.1.23)

This enzyme can be demonstrated histochemically in neoplastic tissues (Lanzerotti and Gullino, 1972) and probably catabolizes glycosaminoglycans (Distler and Jourdian, 1973). Its role, if any, in malignant infiltration apparently has not been studied.

5. Hexosaminidase ( $\beta$ - $\mathrm{N}$-acetylglucosaminidase: $\beta$ 2-acetamido-2-deoxy-D-glucoside acetamidodeoxyglucohydrolase: EC 3.2.1.30)

In recent years this enzyme has been the subject of intense scrutiny, largely because of its role in the pathogenesis of Tay-Sachs disease (Lowden et al, 1973). It is important for the degradation of glycosaminoglycans (Hall et al, 1973), and the serum shows increased activity in pregnancy (Stirling, 1972) and inflammation (Kar and Pearson, 1973). Its lysosomal situation can be shown histochemically (Pugh, 1972), and experimental tumours exhibit high activity (Carr, 1965).

\section{Patients}

The series consisted of 60 pleural and 27 peritoneal effusions from 87 patients. Only the first submitted specimen from each patient was included, since later experience showed that local antimitotic agents, systemic antibiotics, and repeated aspiration could alter enzyme activities in a rather unpredictable manner. No effusion was included unless the underlying pathology was known with certainty; this required careful assessment of clinical, cytological, histological, and necropsy information. Although more than 200 effusions were analysed during the course of the series, most did not meet these criteria and could not be included.

Aspirates were submitted fresh and without added fixative for routine cytological examination. The specimens were immediately centrifuged at $1000 \mathrm{~g}$ for 10 minutes, and smears and blocks were prepared from the cellular deposit. The supernatant was used without modification for enzyme assay as detailed below. Assay was performed as soon as possible after receipt of the specimen, but if delay was unavoidable the supernatant was stored at $4^{\circ} \mathrm{C}$ for not more than 16 hours. Serial assays showed that under these conditions there was no significant decay in enzyme activity.

The effusions ultimately were grouped according to their known aetiology (table I).

\begin{tabular}{lllll}
\hline Effusion & Benign & Malignant & Inflammatory & Total \\
\hline Pleural & 17 & 34 & 9 & 60 \\
Peritoneal & 5 & 22 & 0 & 27 \\
\hline
\end{tabular}

Table I Distribution of the effusions

\section{BENIGN}

This group comprised patients with cardiac failure, renal failure, and hepatic cirrhosis.

\section{MALIGNANT}

Patients with sarcomas and malignant lymphomas were excluded, since only a very few specimens were available from these sources. All the common epithelial tumours were represented, with predictably notable contributions from carcinomas of breast, bronchus, ovary, and gastrointestinal tract.

\section{INFLAMMATORY}

No inflammatory peritoneal effusions were available. The nine pleural effusions in this group were associated with oesophageal perforation, postthoracotomy sepsis, idiopathic chronic pleuritis, pulmonary infarction, and post-pneumonic empyema. Tuberculous effusions were not included.

\section{Methods}

Protein was measured by the method of Lowry et al (1951). 
In all enzyme assays, tubes containing appropriate volumes of substrate and effusion were incubated separately and mixed immediately before the addition of terminating alkali: the resultant mixture served as the control tube.

\section{$\beta$-GLUCURONIDASE}

$0.025 \mathrm{M}$ phenolphthalein glucuronide was prepared from the cinchonidine derivative according to the instructions of the Sigma Chemical Company (Technical Bulletin No. 105, p. 5, December 1958). Of this solution $0.5 \mathrm{ml}$ was incubated for 24 hours at $37^{\circ} \mathrm{C}$ with $0.5 \mathrm{ml}$ effusion and $3.0 \mathrm{ml} 0.05 \mathrm{M}$ acetate buffer, $\mathrm{pH} 4 \cdot 5$. The reaction was stopped by adding $4.0 \mathrm{ml} 0.4 \mathrm{M}$ glycine buffer, $\mathrm{pH} 10.8$, and the released phenolphthalein was estimated by measuring the optical density at $545 \mathrm{~m} \mu$ in a Pye Unicam SP500 spectrophotometer. Unit enzyme activity was that amount of enzyme which liberated $1 \mu \mathrm{g}$ phenolphthalein in 24 hours.

\section{$\alpha$-MANNOSIDASE}

This is essentially a modification of the method of Saita et al (1971). Two millilitres of $0.001 \mathrm{M} \mathrm{p}$ nitrophenyl- $\alpha-\mathrm{D}$ mannoside in $0 \cdot 2 \mathrm{M}$ acetate buffer, pH 4.0, with $0.3 \mathrm{mM} \mathrm{ZnSO}_{4}$ was incubated with 1.0 $\mathrm{ml}$ effusion at $37^{\circ} \mathrm{C}$ for 1 hour. The reaction was terminated with $4.0 \mathrm{ml} 0.4 \mathrm{M}$ glycine buffer, $\mathrm{pH}$ $10 \cdot 8$, and the released p-nitrophenol was estimated by measuring the optical density at $430 \mathrm{~m} \mu$. Unit enzyme activity was that amount of enzyme which liberated $1 \mu \mathrm{g}$ p-nitrophenol in 1 hour.

ARYLSULPHATASE A

This was assayed by the method of Baum et al (1959), as described for serum.

\section{$\beta$-GALACTOSIDASE}

One millilitre effusion was incubated at $37^{\circ} \mathrm{C}$ for 24 hours with $2.0 \mathrm{ml} 0.0166 \mathrm{M} 0$-nitrophenyl- $\beta$-Dgalactopyranoside in $0.1 \mathrm{M}$ acetate buffer, $\mathrm{pH} 4.7$, and the reaction was stopped by adding $4.0 \mathrm{ml}$ $0.4 \mathrm{M}$ glycine buffer, $\mathrm{pH} 10 \cdot 8$. Optical density was read at $\mathbf{4 0 5} \mathrm{m} \mu$ and unit enzyme activity was defined as that amount of enzyme which liberated $1 \mu \mathrm{g} \mathrm{p}$ nitrophenol in 24 hours.

\section{HEXOSAMINIDASE}

One millilitre effusion was incubated at $37^{\circ} \mathrm{C}$ for 10 hour with $2.0 \mathrm{ml} 0.0087 \mathrm{M}$ p-nitrophenyl- $\beta-\mathrm{N}$ acetylglucosaminide in $0.05 \mathrm{M}$ citrate buffer, $\mathrm{pH}$ $4 \cdot 3$, with $0 \cdot 1 \mathrm{M} \mathrm{NaCl}$. The reaction was stopped witho $4.0 \mathrm{ml}$ glycine buffer, $\mathrm{pH} 10.8$, and the optical densityo was read at $430 \mathrm{~m} \mu$. Unit enzyme activity was thats amount of enzyme which liberated $1 \mu \mathrm{g}$ p-nitro $\Omega$ phenol in 1 hour.

In the cases of $\beta$-glucuronidase, hexosaminidase, and $\beta$-galactosidase, no attempt was made to standardize the assay procedures with those of other $\vec{\omega}$ workers, which are, in any case, diverse. Theog methods chosen are those which have been used for some years in this laboratory and which have thei advantages of familiarity and reproducibility.

Results were calculated as units per $\mathrm{ml}(\mathrm{mIU} / \mathrm{mL}$ in the case of arylsulphatase A) and as specific activity, ie, units per $\mathrm{mg}$ protein.

\section{Results}

It soon became apparent that expressing results as specific activities gave a large scatter of values with $\overrightarrow{0}$ no correlation between the benign, malignant, a $8 \mathrm{~d} 5$ inflammatory groups. The fact that the specito activity of any one enzyme was not constant withi group, or between groups, indicated that the leves of these enzymes was independent of the proteing content. Consequently, the results, summarized ino table II are expressed as units per $\mathrm{ml}$.

Each of the enzymes shows a gradual increase in activity from benign through malignant to inflam $-\frac{3}{5}$ matory lesions, and these observations accord with the fact that lysosomal hydrolases are substantially concerned with the dissolution of intercellulan ground substances. It is apparent that in each caseo there is a spectrum of activity, with a degree of over lap in the various aetiological groups.

The technique of discriminant analysis was em ployed to find the best combination of enzymes tog discriminate between benign, malignant, and inflam- $\rightarrow$ matory effusions. The two enzymes, hexosaminidase and $\alpha$-mannosidase, gave the best separation. From the derived graph of hexosaminidase against $\alpha=\Omega$

\begin{tabular}{|c|c|c|c|c|c|c|c|c|c|}
\hline \multirow[t]{2}{*}{ Enzyme } & \multicolumn{3}{|l|}{ Benign } & \multicolumn{3}{|l|}{ Malignant } & \multicolumn{3}{|l|}{ Inflammatory } \\
\hline & Range & Mean & $S E$ & Range & Mean & $S E$ & Range & Mean & $S E$ \\
\hline $\begin{array}{l}\text { Hexosaminidase } \\
\text { Arylsulphatase A } \\
\beta-\text {-Galactosidase } \\
\beta-\text {-Glucuronidase } \\
\text { a-Mannosidase }\end{array}$ & $\begin{array}{c}16 \cdot 5-97 \cdot 5 \\
0-0 \cdot 201 \\
0-33 \cdot 0 \\
5 \cdot 8-37 \cdot 1 \\
0-26 \cdot 3\end{array}$ & $\begin{array}{c}64 \cdot 5 \\
0 \cdot 042 \\
6 \cdot 8 \\
13 \cdot 4 \\
9 \cdot 9\end{array}$ & $\begin{array}{l}4 \cdot 6 \\
0 \cdot 014 \\
2 \cdot 1 \\
1 \cdot 5 \\
1 \cdot 5\end{array}$ & $\begin{array}{c}55 \cdot 5-555 \cdot 0 \\
0-0 \cdot 773 \\
0-42 \cdot 6 \\
6 \cdot 4-185 \cdot 6 \\
6 \cdot 0-45 \cdot 0\end{array}$ & $\begin{array}{c}164 \cdot 0 \\
0 \cdot 083 \\
13 \cdot 2 \\
26 \cdot 7 \\
12 \cdot 3\end{array}$ & $\begin{array}{c}12 \cdot 8 \\
0 \cdot 017 \\
1 \cdot 4 \\
3 \cdot 4 \\
1 \cdot 2\end{array}$ & $\begin{array}{c}300 \cdot 0-1140 \cdot 0 \\
0-4 \cdot 166 \\
22 \cdot 0-1140 \cdot 0 \\
31 \cdot 3-290 \cdot 0 \\
15 \cdot 0-255 \cdot 0\end{array}$ & $\begin{array}{c}606 \cdot 0 \\
0 \cdot 867 \\
194 \cdot 0 \\
176 \cdot 0 \\
130 \cdot 0\end{array}$ & $\begin{array}{c}105 \cdot 0 \\
0 \cdot 423 \\
119 \cdot 0 \\
32 \cdot 2 \\
28 \cdot 9\end{array}$ \\
\hline
\end{tabular}


mannosidase the following limits were selected (table III).

Application of these criteria to the individual samples in the series showed that, on the basis of enzyme content, $95 \%$ of malignant effusions could be classified as malignant, but that roughly one quarter of both the benign and inflammatory effusions also fell into this category (table IV).

\begin{tabular}{lll}
\hline & Hexosaminidase & a-Mannosidase \\
\hline Benign & less than $80 \mathrm{units} / \mathrm{ml}$ & less than $65 \mathrm{units} / \mathrm{ml}$ \\
Malignant & more than $80 \mathrm{units} / \mathrm{ml}$ & less than $65 \mathrm{units} / \mathrm{ml}$ \\
Inflammatory & more than $80 \mathrm{units} / \mathrm{ml}$ & more than $65 \mathrm{units} / \mathrm{ml}$
\end{tabular}

Table III Diagnostic hydrolase ranges for pleural and peritoneal effusions

\begin{tabular}{|c|c|c|c|c|c|}
\hline \multirow[t]{2}{*}{ True Diagnosis } & \multirow[t]{2}{*}{ Total } & \multicolumn{3}{|c|}{$\begin{array}{l}\text { Classification by Enzyme } \\
\text { Measurement }\end{array}$} & \multirow[t]{2}{*}{ Concordance } \\
\hline & & Benign & $\begin{array}{l}\text { Malig- } \\
\text { nant }\end{array}$ & $\begin{array}{l}\text { Inflam- } \\
\text { matory }\end{array}$ & \\
\hline $\begin{array}{l}\text { Benign } \\
\text { Malignant } \\
\text { Inflammatory }\end{array}$ & $\begin{array}{r}22 \\
56 \\
9\end{array}$ & $\begin{array}{r}17 \\
3 \\
0\end{array}$ & $\begin{array}{r}5 \\
53 \\
2\end{array}$ & $\begin{array}{l}0 \\
0 \\
7\end{array}$ & $\begin{array}{l}77 \% \\
95 \% \\
78 \%\end{array}$ \\
\hline
\end{tabular}

Table IV Correlation between true diagnosis and diagnosis by enzyme assay

\section{CYTOLOGICAL EXAMINATION}

In each case, cytological examination of the effusion was undertaken as a routine procedure by a member of the division of cytology within this department. No false diagnosis of malignancy was made. In the case of malignant effusions, tumour cells were demonstrated in $76 \%$ of the peritoneal and in $62 \%$ of the pleural aspirates. Thus there was an overall success rate of $67 \%$ in the cytological diagnosis of malignancy.

\section{CORRELATION BETWEEN CYTOLOGY AND ENZYMOLOGY}

Two malignant pleural effusions and no malignant peritoneal effusion had hexosaminidase levels of less than 80 units $/ \mathrm{ml}$ and falsely fell within the 'benign' range. In neither of these specimens were malignant cells identified.

Sixteen cases of malignant ascites contained malignant cells; all had levels of hexosaminidase more than 80 units $/ \mathrm{ml}(\alpha$-mannosidase less than 65 units $/ \mathrm{ml}$ ) and were in the 'malignant' range. Five cases of malignant ascites did not contain malignant cells but demonstrated enzyme activities within the 'malignant' range. The average hexosaminidase activities of the malignant peritoneal effusions with and without malignant cells were not significantly different.
Thirty-two of the 34 malignant pleural effusions had 'malignant' enzyme activities. Twenty-one samples contained malignant cells, but 11 samples did not; there was no significant difference between the average hexosaminidase activities in either group.

Although those effusions which contained the most numerous malignant cells tended to have higher hexosaminidase levels, this was by no means always the case, and the malignant effusion with the highest observed hexosaminidase activity (555 units/ $\mathrm{ml}$ ) did not, in fact, contain identifiable tumour cells. Hence, there was no good correlation between hexosaminidase levels and the presence or absence of malignant cells within an effusion.

\section{Discussion}

It is not necessary here to go into detailed consideration of the role of lysosomal glycosidases in tissue infiltration by malignant cells. Carr (1965) has given a synopsis of the underlying theories along with his own supporting experimental evidence, and a comprehensive monograph on the subject has been published (Cameron, 1966).

Glycosaminoglycan breakdown occurs, as far as we know, in its most extreme form in acute inflammation (Feher et al, 1971), and it was found that the inflammatory effusions reflected the intensity of this process; all of the hydrolases measured showed highest activities in inflammatory effusions, with the exception of two cases which had previous heavy antibiotic therapy and exhibited uncharacteristically low values. The fact that the majority of malignant effusions showed higher activities than the benign transudates seems to offer further supporting evidence that there is significant ground substance destruction during the process of invasion. While in a minority of the cases this could be attributable to co-existing inflammation, it is common histological experience that most infiltrating tumours are not attended by visible signs of inflammation. The most logical, and attractive, explanation is that the tumour cells themselves release lysosomal enzymes; a wealth of experimental evidence built up over the last 50 years shows this to be true.

If it is accepted that carcinoma cells secrete glycosidases, some comment on the nature of those effusions which are associated with and are enzymologically indicative of underlying malignancy, but which are cytologically negative for malignant cells, is necessary. Eleven pleural effusions of this type containing typically 'malignant' enzyme activities were encountered. Carr (1965) showed that viable experimental tumour cells, free in a body cavity and no longer actively infiltrating, to a large extent cease secretion of glycosidases. If such a process occurs in 
human malignancy, then the glycosidase activity of an effusion is dependent not upon free-floating cells but upon diffusion from those cells which are infiltrating the surrounding tissues of the body cavity. This would explain why the enzyme levels of effusions bear no strong relation to the number of malignant cells observed in those effusions, and why cytologically negative effusions may yet contain hydrolase activities within the 'malignant' range.

Benign transudates show characteristically low hydrolase activities, and the lowest values encountered in this series were found in ascites secondary to cirrhosis of the liver. The hexosaminidase levels of benign pleural effusions were more variable, and the five specimens which comprised the "false malignant' results in this group had activities between 84 and 95 units $/ \mathrm{ml}$. No benign effusion had a hexosaminidase level of more than 95 units $/ \mathrm{ml}$.

Any attempt to draw up diagnostic levels from this information suffers from the disadvantage that the characteristic enzyme ranges for each underlying pathology (benign, malignant, and inflammatory) merge into one another, a difficulty commonly found in chemical pathology. Moreover, there are inhibitors (and perhaps activators) of these enzymes present in body cavity effusions, and relatively little is known of their nature and quantity, or whether they vary significantly from case to case. Nevertheless, the fact remains that $95 \%$ of all malignant effusions have hexosaminidase and $\alpha$-mannosidase levels within definable limits, and that more than three-quarters of all inflammatory and other nonneoplastic effusions have levels outwith these limits. There is a 'zone of uncertainty' which is bounded by hexosaminidase levels of $84-95$ units $/ \mathrm{ml}$, but relatively few specimens are included in this range, and it would seem that this method of typifying peritoneal and pleural effusions could have real diagnostic value for the clinician, especially when repeated samples from suspected cases of malignancy fail to demonstrate neoplastic cells. It is proposed to carry on this work as a prospective trial for further evaluation, and to see whether techniques can be improved to yield a greater accuracy.

Thanks are extended to Dr A. J. Carr for encouragement; Professor A. L. Stalker suggested helpful alterations to the original manuscript. The statistical work was performed by Dr G. Hems, Department of Statistics, Aberdeen University, and Miss A. Mackay typed the paper through several drafts.

\section{References}

Baum, H., Dodgson, K. S., and Spencer, B. (1959). The assay of arylsulphatases A and B in human urine. Clin. chim. Acta, 4, 453-455.
Belfiore, F., Vecchio, L. L., and Napoli, E. (1972). Serum $\beta \stackrel{\text { బ }}{=}$ glucuronidase activity in diabetic patients as related to vascular complications and degree of glucose metabolic disorder. Amer. J. Med. Sci., 264, 457-466.

Boyland, E., Wallace, D. M., and Williams, D. C. (1955) The activity of the enzymes sulphatase and $\beta$-glucuronidase in the urine, serum and bladder tissue. Brit. J. Cancer, $9, \frac{\sigma}{\sigma}$ 62-79.

Cameron, E. (1966). Hyaluronidase and Cancer. Pergamon Press, Oxford.

Carr, A. J. (1965). The relation to invasion of glycosidases ing mouse tumours. J. Path. Bact., 89, 239-243.

Carr, D. T. and Power, M. H. (1958). Clinical value of measurements of concentration of protein in pleural fluid. N. Engl. J. Med., 259, 926-927.

Dines, D. E., Elveback, L. R., and McCall, J. T. (1974). Zinc,, copper and iron contents of pleural fluid in benign and neoplastic disease. Mayo Clin. Proc., 49, 102-106.

Distler, J. J. and Jourdian, G. W. (1973). The purification and properties of $\beta$-galactosidase from bovine testes. J. bioliv Chem., 248, 6772-6780.

Dzialoszynski, L. M. (1957). The clinical value of arylsulpha $\vec{N}$ tase estimation in urine. Clin. chim. Acta, 2, 542-547.

Farooqui, A. A. and Bachhawat, B. K. (1971). The regional distribution, age dependent variation and species differences of brain arylsulphatases. J. Neurochem., 18, 635-646.

Feher, J., Jennings, E. H., and Rannie, I. (1971). Histochemical demonstration of $\beta$-glucuronidase activity in experimental inflammation produced by croton oil in rats: Brit. J. exp. Path., 52, 23-26.

Fishman, W. H., Anlyan, A. J., and Gordon, E. (1947). $\beta$-Glucuronidase activity in human tissues: some correआ tions with processes of malignant growth and with \$i physiology of reproduction. Cancer Res., 7, 808-817.

Goldbarg, J. A., Pineda, E. P., Banks, B. M., and Rutenbu政, A. M. (1959). A method for the colorimetric determination of $\beta$-glucuronidase in urine, serum, and tissue: assay ofم్ enzymatic activity in health and disease. Gastroenterology 36, 193-201.

Graham, R. M. (1964). Diagnostic accuracy of cytologic technics. Acta Cytol., 8, 161-162.

Hall, C. W., Cantz, M., and Neufeld, E. F. (1973). A $\beta=\frac{3}{5}$ glucuronidase deficiency mucopolysaccharidosis: studies in cultured fibroblasts. Arch. Biochem. Biophys., 155, 32-38용

Hook, G. E. R., Dodgson, K. S., Rose, F. A., and Worwood M. (1973). Relative distribution of arylsulphatases $A$ and? $\mathrm{B}$ in rat liver parenchymal and other cells. Biochem. J. 134, 191-195.

Kar, N. C. and Pearson, C. M. (1973). Elevated levels on serum $\beta$-acetylglucosaminidase in some patients with rheumatoid arthritis. Proc. Soc. exp. Biol. (N.Y.), 142, 398 400.

Kroh, H. and Renkawek, K. (1973). Cytochemical distribu tion of $\beta$-glucuronidase activity in experimental braino tumours and brain tissue in vivo and in vitro. Histochemie 34, 317-324.

Lanzerotti, R. H. and Gullino, P. M. (1972). Activities and quantities of lysosomal enzymes during mammary tumor regression. Cancer Res., 32, 2679-2685.

Lawson, J. G. (1960). Vaginal fluid $\alpha$-mannosidase. $J$. Obstet. Gynaec. Brit. Emp., 67, 305-308.

Light, R. W., MacGregor, M. I., Luchsinger, P. C., andb Ball, W. C., Jr. (1972). Pleural effusions. The diagnostic separation of transudates and exudates. Ann. intern. Med.s, 77, 507-513.

Lowden, J. A., Skomorowski, M. A., Henderson, F., and Kaback, M. (1973). Automated assay of hexosaminidase? in serum. Clin. Chem., 19, 1345-1349.

Lowry, O. H., Rosebrough, N. J., Farr, A. L., and Randall R. J. (1951). Protein measurement with the Folin pheno? 
reagent. J. Biol. Chem., 193, 265-275.

Niebes, P. (1972). Determination of enzymes and degradation products of glycosaminoglycan metabolism in the serum of healthy and varicose subjects. Clin. chim. Acta, 42, 399-408.

Pineda, E. P., Goldbarg, J. A., Levitan, R., and Rutenburg, A. M. (1962). Leucine aminopeptidase and $\beta$-glucuronidase activity in cancerous and noncancerous effusions. Amer.J. dig. Dis., 7, 797-803.

Pineda, E. P., Goldbarg, J. A., Banks, B. M., and Rutenburg, A. M. (1959). The significance of serum $\beta$-glucuronidase activity in patients with liver disease. Gastroenterology, 36, 202-213.

Pugh, D. (1972). The fine localization of $N$-acetyl- $\beta$-glucosaminidase in rat tissue using an indoxyl substrate. Ann. Histochim., 17, 55-64.

Rome, D. S. (1964). Diagnostic accuracy of cytologic technics. Acta Cytol., 8, 159-161.

Saita, M., Ikenaka, T., and Matsushima, Y. (1971). Isolation and characterization of $a$-D-mannosidase from soy bean. J. Biochem., 70, 827-833.

Schersten, J., Wahlqvist, L., and Jilderos, B. (1971). Lysosomal enzyme activity in liver tissue, kidney tissue, and tumor tissue from patients with renal carcinoma. Cancer (Philad.), 27, 278-283.

Stirling, J. L. (1972). Separation and characterization of $\mathrm{N}$ acetyl- $\beta$-glucosaminidases $A$ and $P$ from maternal serum.
Biochim. Biophys. Acta, 271, 154-162.

Tinney, W. S. and Olsen, A. M. (1945). The significance of fluid in the pleural space: a study of 274 cases. J. thorac. Surg., 14, 248-252.

Woessner, J. F., Jr. (1965). Acid hydrolases of connective tissue. Int. Rev. connect. Tissue Res., 3, 201-260.

\section{Addendum}

Since this paper was submitted for publication, further information concerning one of the patients included in the series has become available. A middle-aged man with recurrent pleural effusions was diagnosed as having idiopathic chronic pleuritis on the basis of an open pleural biopsy specimen. However, the hydrolase content of the pleural effusions was consistently in the 'malignant' range (typical results: hexosaminidase 390 units/ml and $a$-mannosidase 15 units $/ \mathrm{ml}$ ) and he is classed in the series as inflammatory/false malignant.

The patient recently died at another hospital and necropsy revealed a malignant pleural tumour, probably mesothelioma. 